\title{
Advantage India: A Study of Competitive Position of Organized Retail Industry
}

\author{
Dr.Prafulla Arjun Pawar ${ }^{1,}$ Nitin Balaso Veer ${ }^{2}$
}

\begin{abstract}
Organised retail industry is one of the untapped industry sectors in India with huge growth potential. Indian retail sector mainly divided into unorganised and organised retail. Organizes retail has limited market share in this sector. Recently Government of India allowed FDI in single brand retailing and multi brand retail. Due to this decision it will create market opportunity to foreign big retail players to enter into Indian retail market. Organised retailing continues to be the least evolved industries in India and the growth of organized retailing in India much slower as compared to other Asian and European countries. The present paper discusses the competitive advantage of India for FDI in retail sector with the help of National diamond Model suggested by Michael Porter (1990) for competitive advantage of nation. The purpose of the study is to analyse the strategic competitive position of India for investment in retail sector and also analyses the world wide retail market opportunity as compared with Indian retail sector. Analysis of retail industry is done by using various market research reports on retail sector published by market research firm, government publication, and industry news and online resource. Michael Porter's model on competitive advantage of nation is applied here with the help of secondary data and analysed the each determinants of competitiveness of nation. Some of determinant used for analysis from the report published by World Economic Forum. The findings of the study are point out that FDI in retail would undoubtedly enable Indian economy to boost at faster rate than current situation. There are various advantages to foreign retailer to enter into the Indian retail sector. Growth in disposal income and a change in the standard of living of Indian society create demand condition for retail. Absence of bigger organised retail players, largest demand and market size, availability of low cost labour, developing infrastructure, economy of scale and global sourcing are the key market potential indicators for foreign investor to invest in India. It is concluded that foreign direct investment in retail industry will create positive and favourable business opportunity for foreign retailers and all the determinant of competitiveness are positive for retail industry in India.
\end{abstract}

Key Words - Competitive advantage, FDI, Retail, Porter's diamond model, National competitiveness

\section{Introduction}

The analysis of competitive advantage of India in retail is important part of industry analysis in particularly for investment decision. Present research makes use of Michael Porter's "The National Diamond" to describe the present situation in India. It is a good way to figure out why a nation can achieve international success in a retail industry. Recently Government of India is in the favour of passing foreign direct investment bill in single brand and multi-brand retail sector.Porter (1990) advanced the diamond frame to explain above competitive advantage of Nation. Michael Porter used six determinants to analyse competitive advantage of nation or industry such as factor conditions, demand conditions, related and supporting industries, firm strategy, chance and government. The National diamond used to analyze why a certain industry can be developed well in a certain country. Present research also wants to use these six dimensions to analyze that why the retail industry of India can be develop as one of the competitive industry in country. This model suggests that the national home base of demand factor and trade of any industry or country plays an important role in shaping the extent to which it is likely to achieve competitive advantage in particular nation or particular industry sector as compare with advantage on a global competition. This home base provides basic factors of demand condition, which support organizations from building competitive advantages in global competition. Due to this reason Indian government is in the process of allowing foreign direct investment in single brand and multi brand retail. Many of the foreign retailers are interested to invest into India in the retailing sector. Retailer like Wal-mart, Nike, Spencer, Metro already present in the India but all these retailers working on the basis of franchising or joint venture policies. Wal-Mart, Carrefour, IKEA, Spar, Tesco, Best Buys are showing interest in India for investing in the retail business. It is significant to analyse the competitive environment of India retail sector.

\footnotetext{
${ }_{1}^{1}$ Professor, Department of Management Sciences (PUMBA), University of Pune, Pune, India

${ }^{2}$ Research Fellow, Department of Management Sciences (PUMBA),University of Pune, Pune, India 
Research Problem is "Why India is the most favourable country for investing in retail sector?" and another research problem is "which are the most important determinant of competitive advantage of India for investment in retail sector over other countries?

Primary Objective of the study- Present study is to illustrate the competitive advantage of India to Foreign direct investment in the retail sector with the help of Michael Porter's Competitive advantage of nation and Another objective of the study is to analyse prospect of retail sector in India through the various report published by government and private market research firm.

\section{An overview Indian retail Sector-}

According to CRISIL research ( 2012) analysed that the organised retail is penetrated in Indian retail market at the 10\% growth rate. In 2006-07 total retail market was Rs.10 trillion and organised retail had Rs 0.6 trillion (5.4\% of organised retail) market size. In 2011-12 organised retail penetrated with $21 \%$ growth rate and total retail market size is Rs 23 trillion and organised retail has 1.6 trillion market size .CRISIL predicted the growth of Indian retail in 2016-17 will be Rs 47 trillion and market share of organised will be $10 \%$. A.T.Kearney(2012) released report on FDI provides a unique look at the present and future prospect for international investment flows. In their analysis India came on the $2^{\text {nd }}$ ranking in FDI confidence index 2012, it happened because of current stand of Indian government on promotion of FDI policy in India. In 2012 India is emerged as $5^{\text {th }}$ most favourable destination for international retailer to invest in India (A.T.Kearney, 2012).India is one of the most attractive retail destination in the world and FDI inflows in single brand trading during April 2000 to September 2012 stood at US \$4270 million as per data released by Department of Industrial Policy and Promotion. The retail sector account for $22 \%$ of India's GDP and contributes to $8 \%$ of total employment (IBEF, 2012).

\section{FDI Policy in India}

Foreign direct investment is defined by Graham Bannock et.al. As FDI is investment made by any company in a foreign country through the merger and acquisition of a local company or making franchisee of business or the establishment of their own operation on a new site as defined in Dictionary of economics (Legalindia.com, 2011). In simple words, we can also say that FDI refers to capital inflows from abroad that is invested in or to enhance the production capacity of the economy through the different rout of entry into country. Foreign investment in India is governed by the Government of India and the provision of the Foreign Exchange Management Act 1999 (RBI, 2000). The Ministry of commerce and industry is the nodal agency for motoring and reviewing the FDI policy on continued basis and changes in sectoral policy. The FDI Policy is notified through Press Notes by the Secretariat for Industrial Assistance (SIA), Department of Industrial Policy and Promotion (DIPP, 2012).

FDI in multi brand retail: Status: Under planning $51 \%$

- 30 per cent procurement of manufactured products must be from SMEs

- Minimum investment cap is USD100 million

- Minimum 50 per cent of total FDI must be invested in back-end infrastructure

- 50 per cent of the jobs in the retail outlet could be reserved for rural youth and a certain amount of farm produce could be required to be procured from farmers

- To ensure the Public Distribution System (PDS) and Food Security System (FSS), government reserves the right to procure a certain amount of food grains

- Multi brand retail would keep food and commodity prices under control

- Consumers will receive higher quality products at lower prices and better service

FDI in single brand retail: Status: Policy passed $100 \%$

- Products to be sold under the same brand internationally

- Sale of multi brand goods is not allowed, even if produced by the same manufacturer

- For FDI above 51 per cent, 30 per cent sourcing must be from SMEs

- Consumerism of the retail market, Any additional product categories to be sold under single brand retail must first receive additional government approval

\section{Literature review-}

Competitive advantage: The evolution of concept competitive advantage came in the 1970s (South, 1980). South described the process of strategic management and the management of competitive advantage as specifically identifying, developing, and taking advantage of the enclaves through which a tangible and sustainable business edge can be achieved. However, the concept of competitive advantage truly became popular with Porter's works $(1980,1985)$ in the strategic competitive management discipline. According to 
Porter (1990) competitive advantage grows from the value a firm is able to create for its buyers that exceeds the firm's cost of creating the product or service.Karnani (1984) concluded concept of competitive advantage for competitiveness analysis and it results from a combination of cost and differentiation as alternative strategy for competition.Day et.al (1988) stated that competitive advantage is not a single entity, but a complex construct consisting of the sum of many parts, and "there is no common meaning for the term competitive advantage". He stressed that a complete definition must describe not only the state of the advantage of competitiveness but also how that advantage was gained as well with the help of past cases of successful industries in different country. Competitive advantage in their eyes consists of positional and performance superiority as a result of relative to the competition in the skills and resources a business deploys. These skills and resources make up the positional advantages stress on productivity as of cost and differentiation. Thus, a competitive advantage is defined as a significant edge over one's rivals in the marketplace in cost, differentiation.(Porter,1992)conceptualized three generic competitive strategies like cost, differentiation and focus stratergy.Most of the firm uses this generic competitive strategy to differentiate themselves from competitor.

National Competitiveness-The World Economic Forum (2012) in its global competitiveness report 2011-2012 defines competitiveness as "the set of institutions, policies, and factors that determine the level of productivity of a country". National competitiveness as a nation's ability to improve the economic and social welfare of its people through active and purposeful participation in the global market (Ali, 2008).A nation's prosperity depends on its competitiveness, which is based on the productivity with which it produces goods and services. Sound macroeconomic policies and stable political and regularity of institutions are necessary but not sufficient conditions to ensure a prosperous economy. Competitiveness is rooted in a nation's microeconomic fundamentals-the sophistication of company operations and strategies and the quality of the microeconomic business environment in which companies compete. An understanding of the microeconomic foundations of competitiveness is fundamental to national economic policy (Porter, 1990). World Economic Forum considered the determinant for the competitiveness of nation on basis of twelve pillars of competitiveness. These pillars are institutions, infrastructure, microeconomic environment, health and primary education, higher education and training, goods market efficiency, labour market efficiency, financial market development, technological readiness, market size, business sophistication, innovation etc.

\section{Research Methodology:}

The researcher has adopted analytical, descriptive and comparative methodology for carrying out this research. In this research database has been retrieved from books, journals, and newspapers and online databases and on the views of writers in the discipline of Competitiveness. In analysis of competitive advantage of India various report published by government and private industry has used to analyse data. Michael Porter's National diamond model is used to set the hypotheses testing. Hypothesis is evaluated by using proposition of the current scenario of Indian retail industry.

\section{Concept - Michael Porter's National Diamond}

An economical model developed by Michael Porter in his book The Competitive Advantage of Nations, where he published his theory of why particular industries become competitive in particular locations.

\section{Determinants of National advantage:}

1. Government and chance - Important determinant for any investment decision.

2. Factor conditions-The nation's position in factors of production, such as skilled labour or infrastructure, necessary to compete in a given industry.

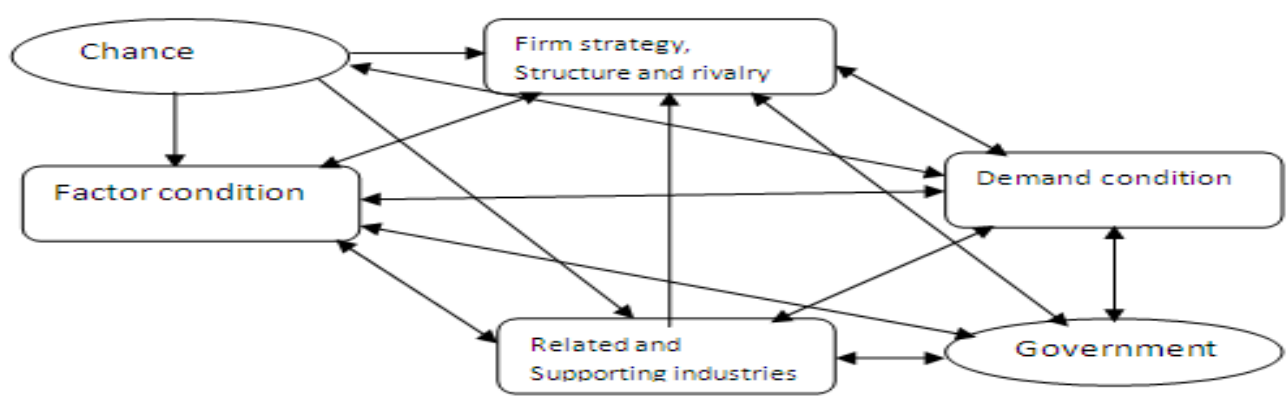

Figure: Michael Porter's National Diamond 
3. Demand condition- The nature of home demand for the industry's product or service.

4. Related and supporting industries - The presence or absence in the nation of supplier industries and related industries that is internationally competitive.

5. Firm strategy, structure and rivalry - The condition in the nation governing how companies created, organised, and managed, and the nature of domestic rivalry.

Implication of Diamond model for competitive Advantages of India for FDI in retail:-

Michael Porter has developed this model for analysis of competitiveness of country and individual industry. In present study analysis of competitive advantage of India for foreign direct investment (FDI) is completed on the basis of Porter's suggested determinant of competitiveness of Nation's and Global competitiveness Report 2011-2012 which is published by World Economic Forum, Geneva, Switzerland. In analysis process government circulars and report, private research report used as a secondary source of data.

Porter's determinant of competitiveness analysis is to be used as follows as:

\section{Government and chance:}

Government can influence each of the four determinants either positively or negatively, as it should be evident from some example related to investment decision in India because government approval is the first entry rout. Before October, 2012 clarification of policies on FDI in retail was restricted to single brand only (Department of Industrial Policy \& Promotion, India April, 2012).Now Government of India approved FDI in single and multi brand on certain rules and regulation. Due to this policy many foreign retailer are entering into the India through direct investment route. They are already entering into India though joint venture e.g.WalMart with Bharti enterprises and Spencer's with RPG group. Chance is another determinant of competitiveness plays important role in the competitive advantage of nation. The European sovereign debt crisis (often referred to as the Eurozone crisis) is an ongoing financial crisis that has made it difficult or impossible for some countries in the euro area to repay or re-finance their government debt without the assistance of third parties. Countries like Spain, Greece, Ireland, Portugal and Cyprus are in bad debt (Haidar,Ibrahim 2012).Eurozone crises shifted the foreign investment in Asian countries. Debt crises situation is not favourable for investment and indirectly India is getting benefits of financial crises in Europe.A.T.Kearney (2012) published report on FDI confidence index 2012 given the $2^{\text {nd }}$ rank to India as favourable investment country. There are some reasons to diversify this investment in India like government decision Eurozone debt crises and demand condition of India. Government also promoting investment policies in multi-brand retail and ready to provide infrastructure and government support to invest in India. These factors are favouring India as place for foreign direct investment (FDI) in retail.

\section{Factor condition-}

Factor of production are often described in very broad term such as land, labour and capital, which are too general to bear on competitive advantage in strategically distinct industries(Michael Porter, 1990).Seventy percentage of Indian population is under age thirty-five (Yaohua S., 2012). Young population is definitely an advantage for economy growth because these are the productive population group. According to UN and Goldman Sachs bank's research report predicted that Indian's population is rising up and now India is the second largest population of the world. Population will increase more five hundred billion in the next forty years. It indicates that labour ability is increasing and the cost of effectiveness is possible through working population. India does possess a number of remarkable strengths in the more advanced and complex drivers of competitiveness. This reversed pattern of development is characteristic of India. The countries boast a vast household market that allows for economies of scale and attract investors. It can rely on a well-developed and sophisticated financial market that can channel financial resources to good use, and it boasts reasonably sophisticated and innovative businesses (World Economic Forum, 2012). Infrastructure is a major sector that propels overall development of the Indian economy. The Secretariat for infrastructure in the planning commission is involved in initiating policies that would ensure time-bound creation of world class infrastructure in the country. This section focuses on power, bridges, dams, roads and urban infrastructure development. Details of the projects, organizations, policies, timelines, schemes, spending on infrastructure are provided for the users (Government of India, 2012).Factor condition grouped into a various categories like human resource, physical resource, knowledge resource, capital resource and infrastructure are favourable in India to established retail industry.

\section{Demand condition-}

Demand condition is another important determinant of national competitiveness.Linder (1961) argues that there must be local demand for product before a nation will export that product, because local demand is necessary to allow local firms to learn how to succeed in the industry. Basically demand condition of any industry is depending on size of home demand, demand size, pattern of growth and number of buyers.Tushar 
Poddar (2012) chief India economist in Global Investment Research Division, Goldman Sachet discusses that India's economic development over the last decade has been quite notable: real GDP growth was approximately $8 \%$ annually over that period, driven by a combination of rising investment as well as consumption demand and greater productivity growth. The country's demographic dividend will be substantial over the next couple of decades. India will add about 110 million workers to its labour force over that time, which is more than the U.S., China, Russia and Japan will add combined. Urbanisation is increasing at the fastest rate over the last 10 years. According to the Ministry of Home Affair India( 2012) estimated in census 2011 that urban population of India is stood at 31.16 per cent which was 27.81 in 2001.Urbanisation of country is right indicator of development and it is growth engine of economy. Purchasing ability of any country is depending on disposable income of country. Disposable incomes of Indian consumers have increased significantly between 2001-02 and 201011. The share of households with low income levels has fallen over the years, while the share of those falling in higher income brackets is on the rise. Going forward, we expect favourable demographics to drive consumption growth (NCAER, CRISIL, 2012)

\section{Related and supporting industries:}

The presence or absence in the nation of supplier industries and related industries that is internationally competitive. Hirschman(1958) stated that in his book economic development emphasize the importance of complementarities and linkage among industries to the development process. India is referred to as the nation of shopkeepers; India has highest density of retail outlets-over 15 million in the world. Most of outlets in India are located in unorganized sector (independent store); the average size of these is much smaller than 500sq.ft. (ASSOCHAM, 2012). India is the world's largest producer of fresh fruits and vegetables, milk, spices, meats, fibrous crops such as jute, several staples such as millets and castor oil seed. India is the second largest producer of wheat and rice, the world's major food staples. India ranked within the world's five largest producers of over $80 \%$ of agricultural products, including many cash crops such as coffee and cotton (Food \& Agricultural Organisation, 2010). Related to retail industry there are various major retails are India like Future Group, Shopper Stop, Trent, Landmark, Reliance, Aditya Birla etc.These above retailers are already in India with hypermarket, Specialty store, departmental store, Superstore formats. India has both related and supplier retail industry and both are positive proposition to get competitive advantage.

\section{Firm strategy, structure and rivalry:}

The competitiveness is depending upon how companies created, organised, and managed, and the nature of domestic rivalry. In the relation of national competitive advantage, India has significant advantage in terms of low labour cost, availability of raw material etc. and many foreign retailers such as Arrow, Levis, JC Penny, Wal-Mart, and Gap are already sourcing their products from India with rising labour cost in developed countries. Many companies are shifting their operation to developing countries such as India and China. WalMart has decisive to set up a completely owned subsidiary in India for product sourcing (Mukharji and Patel, 2005). The organisation goals, strategies, and ways of organizing business are different in every nation. National competitive advantage results from a good match between these choices and the sources of competitive advantage in a particular industry. The way of one firm's management and its competitive form is affected by national circumstances. No one managerial system is universally appropriate. Nations will tend to succeed in industries on the premise that the management practices and modes of organization favoured by the national environment are well suited to the industries sources of competitive advantage (Porter, 1990).

\section{Conclusion and Discussion:}

On analysing of six elements from Michael Porter, India really can grasp the competitive advantage in retail industry. India may have enormous potential for retail business and at the same time various reports suggest that foreign top retail market players are interested to deploy foreign direct investment in Indian retailer sector. All the six determinants of Porter's National diamond are showing favourable indicator for competitiveness of retail industry. A factor of competitiveness is support to the proposition of FDI in India. Analysis of competitiveness review sincerely hopes that this paper is a good implement to understand national competitive advantage of India for FDI in retail.

India can get advantage of high market demand, largest market size, economy of scale, low penetration of retail and global sourcing for retail sector. It can be conclude that India is favourable for the foreign retail players to invest in India.

\section{Bibliography}

[1]. Porter, M. (1990). Competitive Advantage. New York: The Free Press.

[2]. CRISIL. (2012). Organized retail: Decoding the India retail story. Pune: Crisil Research.

[3]. A.T.Kearney. (2012). FDI Confidence Index. A.T.Kearney.

[4]. A.T.Kearney. (2012). Global Retail Expansion: Keep on moving. A.T.Kearney. 
[5]. IBEF. (2012). $\quad$ Retail. $\quad$ Retrieved $\quad$ January http://www.ibef.org/artdispview.aspx?in=63\&art_id=33068\&cat_id=376\&page=1

[6]. Legalindia.com. (2011). Foreign Direct Investment in Indian Retail Sector - An Analysis. Retrieved January 2013, from http://www.legalindia.in/foreign-direct-investment-in-indian-retail-sector-\%E2\%80\%93-an-analysis

[7]. RBI. (2000, May 17). Foreign Exchange Management regulation. Retrieved December 2012, from ttp://rbi.org.in/scripts/BS_FemaNotifications.aspx?Id=164

[8]. DIPP. (2012, April). Consolidated Fdi Policy. Retrieved January 2013, from http://dipp.nic.in/English/Policies/FDI_Circular_01_2012.pdf

[9]. South, S. E. (Spring 1980). Competitive Advantage:The Corner of Strategic Thinking. The Journal of Business Strategy , $15-25$.

[10]. Porter, M. (1990). Competition and Economic Development. Retrieved January 4, 2012, from http://www.isc.hbs.edu/econnatlcomp.htm

[11]. Karnani, A. (1984). Generic Competitive Strategies-An Analytical Approach. Srategic Management Journal (6), $329-334$.

[12]. Day, G. S. (1988). Assessing Advantage: A Framework for Diagnosing Competitive Superiority. Journal of Marketing (52), 1-20.

[13]. Porter, M. (1992). Competetive Strategy (1 st ed.). New York: The Free Press.

[14]. WEF. (2012). The Global Competitiveness Report 2011-2012. Davos: World Economic Forum.

[15]. Ali, A. J. (2008). National competitiveness in a changing world", Competitiveness Review: , An International Business incorporated Journal of Global Competitiveness , 18 No.3,173.

[16]. Porter, M. (1990). The Competitive advantage of Nation. New York: The Free Press.

[17]. Haidar, J. I. (2012). Sovereign Credit Risk in the Eurozone. World Economic Journal , 13(1), $123-136$.

[18]. Yaohua, S. (2012, February). India in 2032 as the third largest economy. Business Week, pp. 112-113.

[19]. Government of India, P. C. (2012). The secratriat for Infrastructure. Retrieved December 27, 2012, from http://infrastructure.gov.in/

[20]. Linder, S. (1961). An Essay on Trade and Transformation. Jhon Willy \& Sons , 167.

[21]. Tushar Poddar. (2012, Febuarary). A View from India. Retrieved 2013, from WWW.Goldmansachet.com: http://www.goldmansachs.com/our-thinking/view-from/a-view-from-india/index.html

[22]. Ministry of Home Affair, G. (2012). India At A Glance : Census 2011. Retrieved January 2012, from http://censusindia.gov.in/2011-prov-results/indiaatglance.html.

[23]. http://www.ncaer.org/research04.html

[24]. Hirschman. (1958). The Strategy of Economic Development (15 ed.). New Haven: Yale University Press.

[25]. Assocham. (2012). $\quad$ www.assocham.org. $\quad$ Retrieved http://www.assocham.org/search/search.php?query=size+of+retail+in+india\&search=1

[26]. F. A.O (2010). http://en.wikipedia.org/wiki/Agriculture in India. Retrieved Jan 2012, from http://en.wikipedia.org/wiki/Agriculture in India - cite ref-faostat.fao.org 2-1

[27]. Mukharji and Patel (2005). FDI in Retail Sector Academic Foundation, New Delhi . New Delhi : Academic Foundation. 